\title{
Ethno-pharmacological use of Ethiopian indigenous forest honey: the case of Sheka forest
}

Minyahel Tilahun ( $\square$ minyahel.tilahun@wku.edu.et)

Wolkite University

\section{Tena Alemu}

Wolkite University

Shimelis Mengistu

Wolkite University

Wondessen Ayalew

Wolkite University

Abera Hailu

Addis Ababa University

\section{Research Article}

Keywords: Ethno pharmacology, Honey type, indigenous forest, plant species, Sheka

Posted Date: March 9th, 2021

DOl: https://doi.org/10.21203/rs.3.rs-306728/v1

License: (c) (1) This work is licensed under a Creative Commons Attribution 4.0 International License. Read Full License 
1 Ethno-pharmacological use of Ethiopian indigenous forest honey: the case of

2 Sheka forest

3

4 Minyahel Tilahun $^{*}$, Shimelis Mengistu ${ }^{1}$, Tena Alemu ${ }^{1}$,Wondessen Ayalew ${ }^{1}$ and Abera Hailu ${ }^{1,2}$

5

$6 \quad{ }^{1}$ College of Agriculture and Natural resources, Wolkite University, Wolkite, Ethiopia

7

$8 \quad{ }^{2}$ College of Natural Sciences, Addis Ababa University, Addis Ababa, Ethiopia

9

10 Correspondence should be addressed to Minyahel Tilahun; Email address: - $\mathrm{ftminyahil@gmail.com;}$

11 minyahel.tilahun@wku.edu.et. ORCid, 0000-0002-1469-191X

12

13

14

15

16

17

18

19

20

21

22

23

24

25

26 


\section{Ethno-pharmacological use of Ethiopian indigenous forest honey: the case of 2 Sheka forest}

Abstract

Background: Sheka forest is the last indigenous forest in Ethiopia. Plant species are important for the production of different honey types used for both consumption and healing purpose. Healing purposes of plant species used for honey production has not been well documented. Documentation of the community honey based ethno pharmacological knowledge can provide huge significance in the process of subjective interpretation.

Materials and Methods: The study employed ethnographic descriptive and explanatory research design which participate 40 healers from Sheka forest, Ethiopia Quantitative analytical tools such as relative frequency citation (RFC), use value (UV), cultural importance index (CI), relative importance (RI), frequency index (FI) and informants consensus factor (ICF).

Results: Six major plant species have been identified in the study area. Honey made from Scheflera abyssinica (Geteme) had higher relative importance (1.67), relative frequency citations (0.55), citation index and frequency index (100). Honey from Vernonia amygdaline (Girawa) was used basically to treat human ailments such as diarrhea and Tonsillitis. Honey from Ficus vasta (Sholla) was primarily used to treat coughing, itching and allergy. Syzgiu guineense (Dokima) and Guizotia schimperi (Meskel Abeba) honeys were primarily used as cosmetics and to protect skin from excessive cold. Scheflera abyssinica honey was used for treat of almost all of the above listed ailments. Ailments like cosmetics and excessive cold, Tonsillitis and Itching and Allergy had a higher Informant Consensus Factor (ICF) of 0.86, 220.82 and 0.80, respectively. Wound and Foot and Mouth diseases were the only two livestock ailments treated by five different honey types.

Conclusion: Six plant species used for medicinal honey production that treated eight ailments have been identified. Scheflera abyssinica (Geteme) honey used for the treatment of eight human ailments. Honey treatment for Tonsillitis and itching and allergy had a higher Informant Consensus 27 Factor.

Key words: Ethno pharmacology; Honey type; indigenous forest; plant species; Sheka 


\section{Background}

2 Forest is the heart of environment and covers one third of the world's land mass [1]. It welfares

3 regional climate, biodiversity, greenhouse effects, purifies air and water pollution [2].As to World

4 Bank[3], Suriname is the first most tree covered country of the world with $98 \%$ coverage. Ethiopia's

5 forests cover is about $15.7 \%$ of the country's land area [4] and generates $12.86 \%$ of GDP in 2012

6 and 2013 [5]. Flowers which give beauty to forest help bees to produce honey. In Ethiopia, there are

7 over 800 identified honey bee forages [6]. Sheka forest is the last indigenous forest in Ethiopia [7]

8 with 125,000 traditional hives, and the forest has been recognized as a biosphere reserve under the

9 patronage of UNESCO [8]. The forest is rich in biodiversity, including 55 endemic plant species to

10 Ethiopia. The forest follows traditional management practices based on religious taboos and

11 customary tenure rights [8]. Based on morphometric and geographical distribution analysis,

12 honeybees from and around Sheka forest are classified as Apis mellifera scutellata [9] and produces

13 large volume and different types of honey annually [4].

Honey gives numerous biological, biochemical and physiological benefits to humans as

15 well as to animals. Natural honey contains about 200 substances, including amino acids, vitamins, 16 minerals and enzymes [10]. Nearly all honey worldwide contains similar types of phenolic acids

17 with unique nutritional and medicinal properties, and the components act synergistic, lending honey 18 utility in a variety of applications [11]. Honey types differ primarily based on the plants from which 19 the bees collect raw material. In addition climatic conditions and geographical region are also the 20 source of the difference for available types of honey [11]. Honey type may be classified as mono 21 flora or multi floral depending on whether a dominating pollen grain, originated from one particular 22 plant or no dominant pollen type is found (multi floral honey)[12]. In Ethiopia, over 6,600 higher 23 plant species are available [13], 400 herbs and shrubs; 100 trees are uses as bee flora [14]. 
Human use of honey is traced back to some 8000 years ago, and the first written reference to

2 honey medicinal use dating back to 2100 - 2000 B.C [10]. Currently, a large proportion of world

3 population prefers to patronize complementary and alternative medicine (CAM) due to its numerous

4 advantages (affordability, availability and lower side effects) compared to the synthetic or standard

5 drugs [15]. Approximately $25 \%$ of modern drugs are derived from natural products [16]. Honey in

6 general has various medicinal uses such as, reducing irritation associated with allergic rhinitis,

7 cough, and asthma. Ingestion can also help with symptoms stemming from gastric ulcer. Topical use

8 includes treatment of wounds, burns, sunburn, cataracts, skin moisturizer, softener, foot ulcers, and

9 post-herpetic corneal opacities [17-19]. Furthermore, it has beneficial effects on fertility [20]. Honey

10 has also been identified as an ethno-veterinary medicine which can manage ailments such as

11 wounds, lesions and infections [21-24]. There are few honey types in the world such as Manuka

12 honey which is approved as a wound dressing [24] and anti-varicella zoster virus [26]. In addition,

13 Kanuka honey (Kunze aericoides) which shares same family with Manuka honey has also been

14 showing immune-stimulatory properties in vitro [27].

For ethno-pharmacological experimental or clinical investigations, a relevant starting point is 16 to understand who uses traditional medicine [28].To gain new honey ethno pharmacological

17 knowledge, innate and long years of acquired beekeepers and healer's knowledge and skill towards

18 the source and it accuracy of healing is very crucial [28]. Furthermore, quantitatively analysis of 19 ethno-pharmacological use of natural products can provide huge significance in the process of 20 subjective interpretation, experimental trial and drug development [29].Several ethno 21 pharmacological studies and reviews [28, 31-34], has been done in Ethiopia. However, the majorities

22 were purely ethno botanical studies, and studies related to honey medicine based of their plant 23 origion has been very short and overlooked. Globally, various honey related investigations have 
1 been done in best forests and honey bee potential areas from different directions[2,18, 35-

2 37].Scientific support to vast majority of the world research community can give wide and vivid

3 information on honey based medicinal knowledge for further study [10].Hence, this study tried to

4 identify ethno pharmacological use of major honey types of Sheka forest towards treating both

5 human and livestock ailments by employing quantifiable analytical tools.

\section{$6 \quad$ Materials and Methods}

\section{Investigation of Sites}

8 The 772-square-mile Sheka Zone lies nearly $645 \mathrm{~km}$ south of the Ethiopian capital of Addis Ababa 9 and, it is about $330 \mathrm{~km}$ from Jimma city, one of the major cities of southwestern Ethiopia.

10 The zone has three districts namely Masha, Anderacha and Yeki, and nearly half of the zone covered

11 with forest. The Forest remains as one of the few Afromontane forests in the country, and it has long

12 been the major source of livelihood, spiritual practices and supporting diverse wildlife populations

$13[4,8]$. All of these management policies have traditionally been enforced by clan leaders and elders.

14 It has rugged terrain with an altitude ranging from about 1300 to 2600 m.a.s.l. The average annual 15 maximum and minimum temperatures are $30^{\circ} \mathrm{C}$ and $13{ }^{\circ} \mathrm{C}$, respectively. Dense forests cover most 16 of the southern parts of Sheka, where the altitude is below 2500 m.a.s.1 [38]. Within the Sheka 17 Forest, "cultural forests" are dense and large forest areas that are preserved as places of worship, 18 usually close to villages or around hilly areas. Therefore, vast forest areas are protected by the 19 religious taboos associated with ritual sites [39]. 


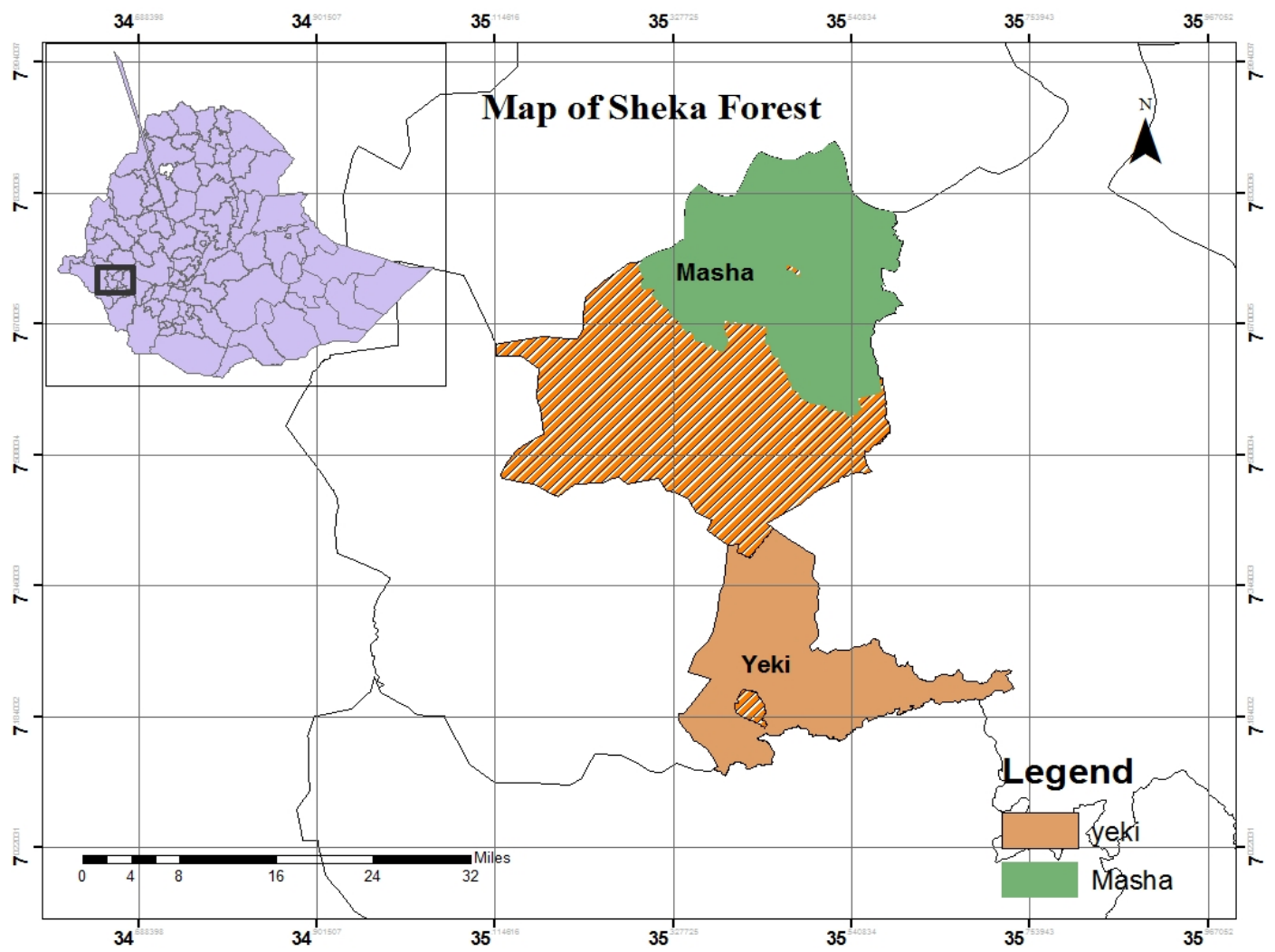

2 Figure 1 Map of the study area

\section{Research design and Ethnographic Science}

4 Descriptive and explanatory research design was employed in two districts of Sheka zone namely

5 Masha and Yeki following formal survey. It focuses on collecting community knowledge towards

6 medicinal uses of honey based on Ethno graphic study principles of collaborative ethnography

7 approach [40]. This collaborative approach was developed for public anthropology which provides

8 ethical and methodological principles useful for ethno-knowledge. Advanced Indigenous skills

9 including field methods were used for assessing the major use of honey and indigenous honey

10 production practices based on product measurement, and native language proficiency. Accuracy of

11 representations was enhanced through a dialectical process among researchers fluent in modes of

12 anthropology and social science. It was clear that the honey produced from each plant species could 
1 not mean the pollen and nectar used for honey production had sole plant source. Honey types in the

2 study area are classified based on the color, taste, smell of the honey while physical test, and

3 abundance and flowering time of the bee floras had also been used as an indicator for honey type

4 classification.

\section{Selection of healers}

6 The informants and traditional healers were selected based on their honey ethno-pharmacological

7 knowledge and experience with the help of zonal administration and elders nominated by the same

8 office. Totally, 40 informants(36 male and 4 female) were selected out of them 36 were male

9 and 4were female from the two districts. All the informants were between the ages of 38-75 years.

10 Table 1. Demographic behavior of Healers of the study area $(\mathrm{N}=40)$

\begin{tabular}{llcc}
\hline Demographic features & & frequency & percentage \\
\hline Age group(years) & $38-50$ & 14 & 35 \\
& $51-60$ & 16 & 40 \\
& $61-70$ & 8 & 20 \\
& Above 70 & 2 & 5 \\
\hline Gender & Male & 36 & 90 \\
& Female & 4 & 10 \\
\hline Education level & Illiterate & 14 & 35 \\
& Elementary and below & 26 & 65 \\
& Secondary & 0 & 0 \\
& Above secondary & 0 & 0 \\
\hline
\end{tabular}

11

12 Data collection method and variety of data collected

13 The data were collected by trained enumerators who spoke Shekicho and have lived in the study area

14 above 10 years. A total of two trips to each healers and key informants house were made between

15 August and October, 2019, and forty respondents were involved in the formal survey. For this

16 purpose, a semi-structured interview guide was prepared in English beforehand and translated in to 
1 the local knowledge "Shekicho" for the purpose of understandability. Interviews with informants

2 were conducted by the researchers with the help of Shekicho translators. During the interview, data

3 regarding the kinds of human and livestock ailments treated or prevented by different medicinal

4 honey types (including their local/ vernacular names) with their source of pollen and nectar, modes

5 of remedy preparations and route of administration were collected. Besides, information regarding

6 different honey bee flora and their seasons of abundance was also gathered. Different honey types

7 from the study area were identified based on long year of experience of the community using

8 different techniques. Honey types are identified and classified based on their color, aroma, test and

9 the abundance of bee floras on a specific season.

\section{Quantitative analysis}

11 Statistical Analysis system for Social sciences [41] and data were organized and analyzed by using

12 Microsoft Excel spreadsheet [42]. Data were presented in tables. The quantitative analysis (relative

13 frequency citation, use value, cultural importance index, relative importance, frequency index and

14 informant consensus factor) was conducted for six most important honey types frequently used in

15 treating both human and livestock ailment according to the information gathered from the selected

16 traditional healers in the study area.

17 Relative frequency citation (RFC)

18 This index is obtained by dividing the number of informants mentioning a useful honey type 19 (FC or frequency of citation), by the total number of informants in the survey (N). RFC 20 value varies from0 (when nobody refers to a honey type as a useful one), to 1 (when all the 21 informants mentioning it as useful) [43]. RFC index, which does not consider the use 
1 category (Use Report (UR) is a single record for use of a plant species mentioned by an

2 individual) and RFC calculated by the following formula:

$$
R F C=\frac{F C s}{N}=\frac{\sum_{\mathrm{i} 1=\mathrm{n}}^{\mathrm{in}} \mathrm{UR \textrm {i }}}{N}
$$

\section{Use value}

5 The use-value (UV) index was used to calculate the citation of honey type during interviews,

6 proposed by [43]. It is calculated as follows:

$7 \quad U V=\sum \frac{U i}{N}$

8 where $U_{\mathrm{i}}$ is the number of uses mentioned by each informant for a given plant species

9 used for honey production and $\mathrm{N}$ is the total number of informants.

\section{Cultural importance index}

11 This index is calculated by the sum of the proportion of informants mentioning each plant 12 species (i.e. the sum of the number of participants who mention the use of each species 13 divided by the total number of informants $(\mathrm{N})$ ) [43]. This index was calculated by the following 14 formula:

$$
C I=\sum_{u=i 1}^{U N c} \sum \frac{U R u i}{N}
$$

\section{Relative importance (RI)}

17 The relative importance of honey type cited by the informants is calculated as follows [44]:

$18 \mathrm{RI}=\mathrm{NP}+\mathrm{NCS}$, where NP is obtained by dividing the number of properties (reported specific

19 ailments) attributed to a honey divided by the total number of properties attributed to the most 
1 versatile honey types (honey with the highest number of properties). NCS is the number of body

2 systems (ailment categories) treated by a given species divided by the total number of body systems

3 treated by the most versatile species. A value of 2 , is the highest possible value for relative

4 importance (RI) indicating the most versatile honey type with the greatest number of

5 medicinal properties.

$6 \quad$ Frequency index

7 To compare the relative importance of each plant species used for honey production, frequency

8 index was calculated. According to [45], frequency index is a numerical expression of the

9 percentage frequency of citation for a single honey type by informants.

$$
F I=F C / N * 100
$$

where $\mathrm{FC}$ is the number of informants who mentioned the use of honey, and $\mathrm{N}$ is the

12 total number of informants in each area.

\section{Informant consensus factor}

14 The informant consensus factor (ICF) was used to see if there was agreement in the use of 15 honey from specific plant species in the ailment categories between the honey users in the 16 study area. The Fic was calculated using the following formula [46].

$17 \quad I C F=\frac{N u r-N t}{N u r-1}$

where $\mathrm{N}_{\mathrm{ur}}$ refers to the number of use-reports for a particular ailment category and $\mathrm{Nt}$ 19 refers to the number of honey type used for a particular ailment category by all informants.

20 The product of this factor ranges from 0 to 1 . A high value (close to 1.0 ) indicates that 21 relatively few honey types are used by a large proportion of the informants. A low value 
1 indicates that the informants disagree on the honey type to be used in the treatment within a

2 category of illness.

\section{Results}

\section{The major pollen and nectar sources of bee floras in Sheka forest}

5 The major pollen bee floras in Sheka forest is presented in Table 2. Twenty nine bee floras were

6 reported for their contribution as source of nectar and pollen in the study area. Asteraceae and

7 Fabaceae families were represented by three species each followed by Boraginaceae and

8 Euphorbiaceae. Among the identified bee floras, 31\% were belongs to cultivated and annual crops,

9 while the rest were significantly sourced from perennial fruit, herbs and trees. Zea mays (Bekolo)

10 was the only species which can provide pollen throughout the year. Vicia faba(Bakela), Croton

11 macrostachus (Bisana), Vernonia spp. (Girawa.), Olea africana (Woiyra) and Scheflera abyssinica

12 (Geteme)were the major pollen sources plants which were agreed by $94 \%$ of the respondents. Only

13 Vicia faba(Bakela) and Scheflera abyssinica (Geteme) were the two plant types that were indicated

14 their use as nectar source by the majority (94\%) of the respondents. Above $50 \%$ of the respondents

15 were agreed up on the use of $11(38 \%)$ of the identified bee floras to be use both for pollen and nectar

16 source. Thirteen bee floras were reported by the above $50 \%$ of the respondents to be used at wet

17 season. However, only four bee floras (Persea americana; Vernonia spp.; Musa paradisiacea; Olea

18 africana) were indicated by above $50 \%$ of the respondents for their significance at dry season. 
Table 2. Bee floras used as Pollen and Nectar sources

\begin{tabular}{|c|c|c|c|c|c|c|c|}
\hline \multirow[t]{2}{*}{ Family } & \multirow[t]{2}{*}{ Voucher No. } & \multirow[t]{2}{*}{ Scientific Name } & \multirow[t]{2}{*}{ Vernacular name } & \multicolumn{4}{|c|}{ Percentage of respondents $(\mathrm{N}=36)$} \\
\hline & & & & Pollen & Nectar & Wet & Dry \\
\hline Anacardiaceae & $M T-s k 120-14$ & Mangifera indica & Mango & 31.25 & 0 & 18.75 & 31.25 \\
\hline Araliaceae & $M T-s k 120-23$ & Scheflera abyssinica & Geteme & $93.75^{*}$ & $93.75^{*}$ & $93.75^{*}$ & 0 \\
\hline \multirow[t]{3}{*}{ Asteraceae } & $M T-s k 120-12$ & Helianthus annuus & Suf & 31.25 & 31.25 & 25 & 18.75 \\
\hline & $M T-s k 120-27$ & Vernonia amygdalina & Grawa & $93.75^{*}$ & 68.75 & 6.25 & 87.5 \\
\hline & $M T-s k 120-10$ & $\begin{array}{l}\text { Guizotia schimperi/ Bidens } \\
\text { spp. }\end{array}$ & $\begin{array}{c}\text { MeskelAbeba/Adeya } \\
\text { beba }\end{array}$ & 81.25 & 81.25 & 81.25 & 0 \\
\hline Braciaceae & $M T-s k 120-13$ & Lepidium sativum & Feto & 6.25 & 6.25 & 12.5 & 0 \\
\hline \multirow[t]{2}{*}{ Boraginaceae } & $M T-s k 120-07$ & Cynoglossum coeruleum & Chogogit & 56.25 & 6.25 & 56.25 & 0 \\
\hline & $M T-s k 120-04$ & Cordia africana & Wanza & 81.25 & 50 & 50 & 31.25 \\
\hline Caricaceae & $M T-s k 120-01$ & Carica papaya $L$. & Pappaya & 12.5 & 25 & 25 & 6.25 \\
\hline Celastraceae & $M T-s k 120-02$ & Catha edulis & Chati & 31.25 & 0 & 0 & 31.25 \\
\hline Cucurbitaceae & MT-sk120-06 & Cucurbita peop & Duba & 62.5 & 6.25 & 62.5 & 0 \\
\hline \multirow[t]{2}{*}{ Euphorbiaceae } & $M T-s k 120-21$ & Ricinus comminus & Gullo & 81.25 & 81.25 & 81.25 & 6.25 \\
\hline & $M T-s k 120-05$ & Croton macrostachus & Bisanna & $93.75^{*}$ & 81.25 & 81.25 & 18.75 \\
\hline \multirow{3}{*}{ Fabaceae } & $M T-s k 120-28$ & Vicia faba & Bakela & $93.75^{*}$ & $93.75^{*}$ & 81.25 & 0 \\
\hline & MT-sk120-19 & Pisum sativum & Ater & 37.5 & 43.75 & 43.75 & 0 \\
\hline & $M T-s k 120-25$ & Sesbania sesban & Sesbania(Girangire) & 25 & 25 & 31.25 & 18.75 \\
\hline Lamiaceae & $M T-s k 120-16$ & Ocimum basilicum & Besobila & 31.25 & 18.75 & 25 & 0 \\
\hline Lauraceae & $M T-s k 120-18$ & Persea americana & Avocado & 81.25 & 6.25 & 50 & 50 \\
\hline Myrataceae & MT-sk120-08 & Eucualyptus & Bahirzaf & 31.25 & 0 & 25 & 18.75 \\
\hline Moraceae & MT-sk120-09 & Ficus vasta & Sholla & 6.25 & & & \\
\hline Musaceae & $M T-s k 120-15$ & Musa paradisiacea & Muz & 68.75 & 81.25 & 56.25 & 62.5 \\
\hline Myrtaceae & $M T-s k 120-24$ & Syzgium guineense & Dokima & 68.75 & 81.25 & 81.25 & 18.75 \\
\hline Oleaceae & $M T-s k 120-17$ & Olea africana & Woyira & $93.75^{*}$ & 56.25 & 31.25 & 68.75 \\
\hline Poaceae & $M T-s k 120-29$ & Zea may & Bekolo & $100^{*}$ & 0 & $100^{*}$ & 0 \\
\hline Rhamnaceae & $M T-s k 120-20$ & Rhamnus prinoides & Gesho & 37.5 & 0 & 12.5 & 31.25 \\
\hline Rutaceae & $M T-s k 120-22$ & Ruta chalepensis & Tena Adam & 25 & 31.25 & 31.25 & 0 \\
\hline Rosaceae & $M T-s k 120-11$ & Hagenia abyssinica & kosso & 62.5 & 62.5 & 56.25 & 0 \\
\hline Rubiacieae & $M T-s k 120-03$ & Coffee arabica & Coffee & 87.5 & 75 & 81.25 & 6.25 \\
\hline Solanaceae & $M T-s k 120-26$ & Solanum tuberosum & Potato & 31.25 & 18.75 & 18.75 & 25 \\
\hline
\end{tabular}

2 Note that ${ }^{*}$ represents bee floras which got preference by above $90 \%$ of the respondents; Four responses were excluded

3 from the above result due to problems during data collection.

4 Medicinal use report for identified honey types

5 Table 3 presents six honey types of Sheka forest which has significant Ethno pharmacological

6 importance. The result indicated that honey types from six plant species which belonged to five

7 families had been used to treat eight human and two livestock ailments. Collectively the ailments

8 were grouped under six physiological problems i.e., Gut/ Alimentary tract, respiratory tract, Skin and

9 face, joints, bone and kidney. Honey from Asteraceae family were the only family which was

10 represented by two plant species (Vernonia amygdalina; Guizotia schimperi). Schefflera abyssinica

11 (Geteme) was with the highest ethno pharmacological quantitative values as compared to the rest 
1 honey types followed by Vernonia amygdalina (Girawa) and Ficus vasta (Shola), respectively.

2 However, Shola honey is higher in some quantitative values i.e., use value (UV) and relative 3 importance (RI) as compared to Grawa Honey. Oral route of honey administration was the major 4 route as compared to other routes followed by topical administration. Teff, Coffee and Bean powders 5 were the major concomitants used by Sheka forest community while administering most of the 6 honey types. 
1 Table 3.Plant species based honey types used to treat human and livestock ailments $(\mathrm{N}=40)$

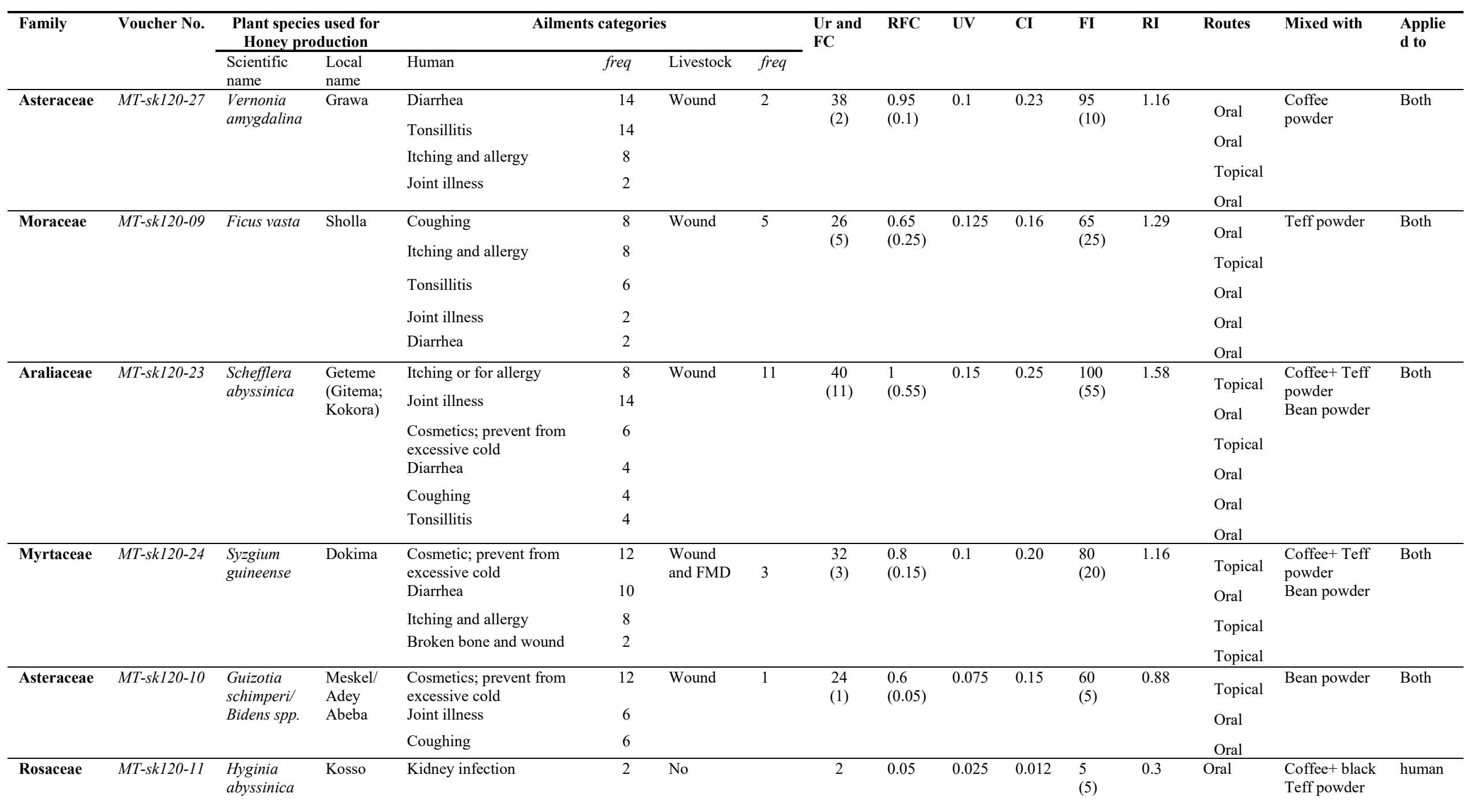

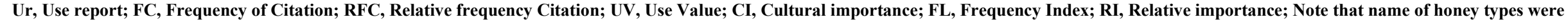
borrowed directly from the local name of plants used as pollen and Nectar source. 


\section{Informant Consensus factor (ICF)}

2 Table 4 presents informant consensus factor (ICF) of Sheka honey type's ability to treat human

3 and livestock ailments. Human aliments, particularly Cosmetics and prevention of face from

4 excessive cold was scored the highest ICF value (0.86) followed by Tonsillitis (0.82) and Itching

5 and allergy (0.8), respectively. There are other ailments treated with eight honey types originated

6 from Sheka forest. Livestock wound treatment was the only ailment with consensus factor (80.9).

7

8 Table 4 Informant consensus factor (ICF) for ailments treated $(\mathrm{N}=40)$

\begin{tabular}{llccc}
\hline SN & Ailments treated & $\begin{array}{c}\text { Number of reports } \\
\left(\mathrm{Nu}_{\mathrm{r})}\right.\end{array}$ & $\begin{array}{c}\text { Number of } \\
\text { honey type }\left(\mathrm{N}_{\mathrm{h}}\right)\end{array}$ & ICF \\
\hline 1 & Itching and allergy & 32 & 4 & 0.8 \\
2 & Joint illness & 24 & 4 & 0.73 \\
3 & Cosmetics; prevent from excessive cold & 30 & 3 & 0.86 \\
4 & Diarrhea & 30 & 4 & 0.79 \\
5 & Coughing & 18 & 3 & 0.75 \\
6 & Tonsillitis & 24 & 3 & 0.82 \\
7 & Broken bone/wound & $2(22)$ & $1(5)$ & $\mathrm{NS}(80.9)^{*}$ \\
8 & Kidney infection & 2 & 1 & $\mathrm{NS}$ \\
\hline
\end{tabular}

$9{ }^{*}$ represents ailments from both human and livestock; the brace indicates value for veterinary use; ICF

10 represents informant consensus factor 
2 Honey inherits plants properties such as color, aroma, flavor, density, and physical and

3 chemical properties which depend on flowers used by bees [47]. Availability of medicinal

4 products in the local vegetation, crop fields and home gardens [4] and ethno pharmacological

5 knowledge acquired through long years of experience [33] have been playing a significant role in

6 local use patterns. Globally, honey food associated studies take a higher emphasis as compared to

7 pharmacological studies. Deliberate health associated or daily feed associated consumption of honey

8 showed a variety of health benefits towards various ailments [11, 18]. The identified twenty nine

9 major bee floras are in line with the study of [48] which have been used as source for different honey

10 type of the study area. Of which, only six ethno-pharmacological honey type sourced from bee flora

11 have been serving the community in healing ailments have been identified. Although the main

12 component of honey is independent of flower origin, some of the components vary depending on the

13 variety of flower used as bee flora [49]. In line with the above result, [38] has reported over 200

14 plant species in Sheka zone. In general, bees obtain pollen from different flowers; however you'll

15 sufficiently get unique honey with linden, orange blossom, lavender, and many others scents. This is

16 due to the abundance and seasonality of flowering plants to serve as bee flora source. Honey type

17 such as Manuka and Kanuka honey which has been used to manage wound and Herpesas an

18 acceptable alternative to acyclovir also has been sourced from the tree Manuka and Kanuka,

19 respectively [27]. In the contrary, many previous studies [11, 50-53] also advertise honey having

20 country's name (Sudanese; Australian; Iranian; New Zealand; Polish and Slovak) with it rather than

21 indicating the specific type of honey from similar origin[11, 51, 52, 54]. Davis [51] also undertakes

22 study on the use of Australian honey on moist wound management. Few medicinal honey types such

23 as India honey has been classified based on their treatment effect [50] rather than classifying based 
1 on their pollen and nectar source. Samarghandian et al. [52] indicates Iranian honey ability to induce

2 apoptosis and inhibit proliferation of PC-3 cells.

$3 \quad$ Honey medicinal use particularly its intake stimulate antibody production during primary and

4 secondary immune responses against antigens [18]. In contrast to this study, previous honey

5 pharmacology related studies [47,53] have indicated various honey types localized to specific

6 geographical area similar to Sheka forest honey with huge benefits in treating different human and

7 livestock ailments. In line with this, [47] has also tried to evaluate clinical importance of different

8 types of honey. This study result indicates the primary ailment which has higher informant

9 consensus factor is cosmetic effect, Tonsillitis and Itching and allergy, respectively. The higher ICF

10 value of the cosmetic effect of honey might be associated with it stability to stimulate tissue

11 regeneration [15]. The new disease treatment effect of Sheka forest honey types as compared to

12 previous studies might also arise due to the presence of bio active agents which might need further

13 study. However, majority of previous studies $[17-19,47]$ reported honey wound management power

14 considerably as compared to other clinical profits. Most of the identified treated ailments are caused

15 by the effect of bacteria, fungus and virus.

16 This study tries to signify honey types such as Getema honey from Schefflera abyssinica tree

17 have numerous and advanced health importance as compared to other prominent honey types such as

18 Vernonia amigdalina (Girawa), Syzgium guineense (Dokima), Ficus vista (Shola) and Meskel Abeba

19 (Guizotia schimperi). Meskel Abeba honey mixed with bean powder has been used to prevent body

20 part particularly face part from excessive cold damage and also used as regular cosmetics. In the

21 contrary, majority of previous studies [54] primarily focus on investigating physicochemical

22 properties of different honeys. The higher proportion of bee flora representation is for the family

23 Asteraceae. Asteraceae is among the largest dicotyledoneous families in the flora of Ethiopia [28]. 
1 Majority of the identified honey types has been applied as prevention or treatments by mixing with

2 Teff, Coffee and bean powder. Ediriweera and Premarathna [18] also reported 10 ways of mixing

3 honey with other ingredients for cosmetic use. Majority of the honey types which were used for

4 treating ailments in this study have been majorly administered through oral route. This result is in

5 line with many plant and animal based ethno pharmacological medicines [28, 31, 33, 34, 58]; ethno

6 zoological products used to treat ailments $[58,59]$. This might be due to the cautious oral

7 administration of honey would render the digestive system aseptic and disease-causing germs would

8 fail to thrive. Oral administration of honey helps to rinse the upper respiratory tract such as throat

9 and trachea and upper digestive system which includes esophagus and stomach till absorption that

10 might be the reason for honey to treat sore throats, coughs, Tonsillitis, colds and diarrhea. Oral

11 means of administration has been accepted by many of the above listed ethno botanical, ethno

12 zoological and honey medicinal use studies. The study also indicated that the primary ailment which

13 has been treated by Sheka honey types is protection against cold damage of the external part of the

14 body particularly face part. This use might be due to the regularity of such kind of ailment in Wurch 15 and Alpine Wurch areas such as Sheka forest.

16 Equivalent to the importance of human ailment management, livestock disease is also a major

17 constraint causing major production losses and threats to livestock production globally. The situation

18 becomes much worsen in developing countries where agriculture is the major means of livelihood

19 and livestock contribution very huge [36]. This study also signifies contributions of honey in treating

20 livestock ailments. Except Hyginia abyssinica (Kosso) honey, all the identified honeys have been

21 used to heal livestock wound. Particularly, Syzgium guineense (Dokima) honey has further treatment

22 effect in treating FMD. In line with this result, Gakuya et al. [21] also reported honey use for treating

23 FMD and lesion in dairy cattle. Similarly, [60] also reported antimicrobial activity of honey against 
1 common equine wound bacterial isolates. Generally, the use of CAM in developing countries

2 remains in use by different communities. However, international ethno-medicinal markets are

3 available [29], products are not easily accessible in the market. So, conservation, documenting,

4 resource management, awareness creation and undertaking vast researches by a range of institutions

5 can bring the hidden knowledge to the surface.

\section{Conclusion}

7 Quantitative analysis of data associated with ethno pharmacology of natural products has

8 indispensable strategic importance in the biomedicine sector to select, examine and identified their

9 medicinal purpose. The wealth of CAM knowledge of honey has great and comparable importance

10 with ethno botanical and ethno zoological knowledge. It has huge significance in the discovery of

11 new drugs to cure ailments. This study concludes that these quantitative analytical tools signify plant

12 species used to produce six distinct honey types i.e., Schefflera abyssinica (Getema), Ficus vasta

13 (Sholla), Syzgium guineense (Dokima) and Vernonia amyigdalina (Girawa), Guizotia schimperi

14 (MeskelAbeba) and Hyginia abyssinica (Kosso) used to treat eight common human and two

15 livestock ailments. Schefflera abyssinica (Getema) honey used to treat more than six human ailments

16 followed by Ficus vasta (Sholla) and Syzgium guineense (Dokima). Cosmetics use and prevention of

17 face from excessive cold was the primary health benefit granted from three different honey types

18 with higher informant's consensus factor followed by Tonsillitis and itching and allergy. The

19 community majorly mix honey with Coffee and Teff powder to treat different human ailments.

20 Further experimental studies on the identified honey types would help to uncover their benefits and

21 extract active ingredients which can replace the existing synthetic drug in the international market. 


\section{Ethics approval and consent to participate}

3 Not applicable.

4 Consent for publication

5 Not applicable.

6 Availability of data and materials

7 The datasets used and/or analyzed during the current study are available from the corresponding

8 author on reasonable request.

9 Competing interests

10 The authors declare that they have no competing interests.

11 Funding

12 Not applicable

\section{Authors' contributions}

14 MM conducted the field research, analyzed the data, and drafted the manuscript. MT, WA, TA, SM 15 and $\mathrm{AH}$ designed the research, interpreted the results, and were involved in the manuscript writing.

16 All authors revised the manuscript and read and approved the final version.

\section{Acknowledgements}

18 The authors pass their acknowledgements to zonal experts, extension agents and respondents who

19 have been helping us at the time of data collection.

\section{REFERENCES}

21 1. World Economic Forum (WEF). The world's most tree covered countries. Sustainable 22 development Summit, 23-24 Sep, 2019, New York, USA. 2019.

23 2. Alireza S, Ensiyeh L, Hadi L, Samaneh K. Estimated value of forest conservation of Gazu forest in Mazandaran. American-Eurasian J. Agric.and Environ. Sci., vol. 13(7):1007-1011, 2013.

3. World Bank. Suriname-Competitiveness and Sector Diversification Project. Washington, D.C.:World Bank Group. 2019. 
http://documents.worldbank.org/curated/en/246651562983310225/Suriname-Competitivenessand-Sector-Diversification-Project.

4. Ministry of Environment, Forest and Climate Change (MEFCC). National Forest Sector Development Program, Ethiopia. vol. I: Situation Analysis. 2018.

5. UNEP.The contribution of forests to national income in Ethiopia and linkageswith REDD+. United Nations Environment Programme: Nairobi.2016.

6. Kebede N, Subramanian PA, Gebrekidan M. Physicochemical Analysis of Tigray Honey: An Attempt to Determine Major Quality Markers of Honey. Bull.Chemical Society of Ethiopia, vol. 26(1), 127-133. 2011. Doi: http://dx.org/10.4314/bcse.v26i1.14.

7. Nuru A. Atlas of pollen grains of major honey bee flora of Ethiopia. 2007.

8. SZA. Sheka Forest Biosphere Reserve Management Plan. website: www.melcaethiopia.org. 2015.

9. Awraris GS, Yemisrach G, Dejen A, Nuru A, Gebeyehu G, Workneh A. Honey production systems (Apis mellifera L.) in Kaffa, Sheka and Bench-Maji zones of Ethiopia. J. Agri Ext Rural Dev, vol. 4(19), pp. 528-541. 2012. DOI: 10.5897/JAERD12.088.

10. Eteraf-Oskouei T, Najafi M. Traditional and Modern Uses of Natural Honey in Human Diseases: A Review. Iran J Basic Med Sci., vol.16: 731-742. 2013.

11. Tomczyk M, Tarapatskyy M, Dzugan M. Theinfluence of geographical origin on honey composition studied by Polish and Slovak honey.Czech J. Food Sci., vol. 37: 232-238. 2019. http://doi.org/10.17221/40/2019-CJFS.

12. Moussa A, Noureddine D, Saad A, Adelmalek M, Salima B. The influence of botanical origin and physic-chemical parameters on the anti-fungal activity of Algerian honey. Plant Pathol. Microbiol., vol. 132, 5.

13. Bekele TA. Useful trees of Ethiopia: identification, propagation and management in 17 agro ecological zones. Nairobi: RELMA in ICRAF Project, p. 552, 2007.

14. Fichti R, Adi A. Honey flora of Ethiopia. CABI. MargrafVerlag, Germany. Pp. 510 pp. ref .80. ISBN 3823612344. 1994.

15. Bogdanov S. Honey in medicine. Book of honey, Chapter 9. Bee product Science, 2016. www.bee-hexagon.net.

16. Newman DJ, Cragg GM. Natural products as sources of new drugs over the 30 years from 1981 to 2010. J. Nat. Prod., vol. 75: 311-35. 2012. Doi: 10.1021/np200906s PMID: 22316239. 
17. Ediriweera ERHSS, Premarathna NYS . Medicinal and cosmetic uses of Bees Honey ; A review. AYU.Vol. 33(2); 178-182.2012. Doi:10.4130/0974-8520.105233.

18. Rao PV, Krishnan KT, Salleh N, Hua GS. Biological and therapeutic effects of honey produced by honey bees and stingless bees: a comparative review. RevistaBrasileira de Farmacognosia 26 (2016) 657-664. 2016. http://dx.doi.org/10.1016/j.bjp.2016.01.012.

19. Hailemeskel B, Fullas F, Habte A, Al-Matari RA, Brewer D. A review of natural remedies commonly used by Ethiopian immigrants in the USA. Curr. Res.Integr. Med., vol. 2 (3): 31-36. 2017.

20. Rajabzadeh A, Sagha M, Gholami MR, Hemmati R. Honey and vitamin E restore the plasma level of gonadal hormones and improve the fertilization capacity in noise-stressed rats. Crescent J. Med. Biol. Sci., vol. 2. 2015a.

21. Gakuya DW, Mulei CM, Wekesa SB. Use of Ethno veterinary remedies in the management of foot and mouth disease lesions in a dairy herd. Afr. J.tradit. Complement. Alt. Med., vol. 8(2): 165-169. 2011.

22. Vandamme L, Heyneman A, Hoeksema H, Verbelen J, Monestry S. Honey in modern wound care: A systematic review. Burns. vol. 39, issue 8, 1514-1525. 2013. http://doi.org/10.1016/j.burns.2013.06.014.

23. Rogalska ME, Tajnik M, Licastro DB, Erica CL, Mattioli C. Therapeutic activity of modified U1 core spliceosomal particles. Nature Communications. 2016. .DOI: 10.1038/ncomms11168.

24. Sami KS, Amor K. Honey and Wound Healing : An update. Americ. J. clinicDerma, vol.18, 237 -251. 2017.http//doi.org/10.1007/s40257-016-0247-8.

25. Alvarez-Suarez JM, Giampieri F, Battino M. Honey as a source of dietary antioxidants: Structures, bioavailability and evidence of protective effects against human chronic diseases. Curr. Med. Chem., vol. 20: 621-638. 2013.

26. Shahzad A, Cohrs RJ. In vitro antiviral activity of honey against varicella zoster virus (VZV): A translational medicine study for potential remedy for shingles. Transl Biomed.., vol. 3(2): 2012. Doi: $10.3823 / 434$.

27. Semprini A, Singer J, Braithwaite I, Shortt N, Thayabaran D, McConnell M, Weatherall M, Beasley R. Kanuka honey versus aciclovir for the topical treatment of herpes simplex labialis: a randomized controlled trial. BMJ Open; 9: e026201. 2019. doi:10.1136/bmjopen-2018-02620. 
28. Gidaya M, Asfaw Z, Woldu Z. Ethno medicinal study of plants used by Sheko ethnic group of Ethiopia. J. Ethno.Pharma., vol.132, 75-85. 2010.

29. Hashim HEK. Medicinal Plants in East and Central Africa: Challenges and Constraints. Ethnobotanical Leaflets, vol.13: 364-69. 2009.

30. Parthiban R, Vijayakumar S, Prabhu S, JobuGEMY. Quantitative traditional knowledge of medicinal plants used to treat livestock diseases from Kudavasaltaluk of Thiruvarur district, Tamil Nadu, India. RevistaBrasileira de Farmacognosia, vol. 26 109-121. 2016.

31. Yirga G, Teferi M, Gidey G, Zerabruk S. An ethno veterinary survey of medicinal plants used to treat livestock diseases in Seharti-Samre district, northern Ethiopia. Afric. J.Plant Sci., vol. 6, no. 3, pp. 113-119. 2012a.

32. Gebrezgabiher G, Kalayou S, Sahle S. An ethno veterinary survey of medicinal plants in woredas of Tigray region. International Journal of Biodiversity and Conservation, vol. 5, pp. 89-97. 2013.

33. Kidane B, Van Der Maesen LJG, Van Andel T; Asfaw Z. Ethno veterinary medicinal plants used by the Maale and Ari ethnic communities in southern Ethiopia.J.Ethnopharmacolo., vol. 153, no. 1, pp. 274-282. 2014.

34. Tilahun M, Shewage T, Etifu M. Plant diversity and its ethno veterinary practices of Ethiopia. Evi. based and Complem med, vol. 2019,Hindawi. 2019.

35. Ramanauskiene K, Stelmakiene A, Briedis, V, Ivanauskas, L, Jaǩstas V. The quantitative analysis of biologically active compounds in Lithuanian honey. Food Chem.,vol.132, 15441548. 2012.

36. Dharani N, Yenesew A, Aynekulu E, Tuei B, Jamnadass R. Traditional ethno veterinary medicine in East Africa: a manual on the use of medicinal plants. Dawson IK ed. The World Agroforestry Centre (ICRAF), Nairobi, Kenya. 2015.

37. Lowore J, Bradbear N. Understanding forest beekeeping in Africa as an efficient forest-resource harvesting system and not a rudimentary system in need of modernization. XIV World Forestry Congress, $\quad$ Durban, $\quad$ South $\quad$ Africa, $\quad$ pp $\quad 7-11$. http://foris.fao.org/wfc2015/api/file/552b61ff9e00c2f116f8e19c/contents/adc15904-372f-43ed9b32-7bbf69d41973.

38. MELCA. 2011. Forest of Sheka. Addis Ababa, Ethiopia. 
39. De Beenhouwer M, Oosterlynck B, Van Opstal M, Shaweno A, Belay M., Erens J. Express Biodiversity Survey in Sheka Forest Biosphere reserve, Ethiopia. Biodiversity Express Survey 5. Biodiversity Inventory for Conservation. Glabbeek, Belgium, 30 pp. 2016.

40. Lassiter LE. Collaborative Ethnography and Public Anthropology.Curr. Anthropol., vol. 46, Number 1. 2005.

41. SPSS Statisticsfor Windows, Version 20.0. Armonk, NY: IBM Corp. IBM Corp. Released 2011.

42. Microsoft Corporation, 2010. Microsoft Excel 2010. Microsoft Corporation.

43. Tardio, J, Pardo-de SM. Cultural importance indices: a comparativeanalysis based on the useful wild plants of southern Cantabria (Northern Spain). Econ. Bot., vol. 62, 24-39. 2008.

44. Hoffman B, Gallaher T. Importance Indices in Ethnobotany. Ethnobot. Res. and Appl., vol. 5:201-218. 2007. www.ethnobotanyjournal.org/vol5/i1547-3465-05-201.

45. Mahwasane ST, Middleton L, Boaduo N. An ethno botanical survey of indigenous knowledge on medicinal plants used by the traditional healers of the Lwamondo area, Limpopo province, South Africa. South African J. Bot., vol. 88,69-75. 2013.

46. Heinrich M, Ankli A, Frei B, Weimann C, Sticher O. Medicinal plants in Mexico: Healers' consensus and cultural importance. Social Science and Medicine. Vol.47:1859-1871. 1998.

47. Manyi-Loh CE, Anna MC, Roland NN. An overview of honey: Therapeutic properties and contribution in nutrition and human health. Afric. J.Microb. Res., vol. 5(8) pp. 844-852, 18 April, 201. 2011. DOI: 10.5897/AJMR10.008.

48. Hailu A. Identification of Honey Source Bee Floras During Major and Minor Harvesting Seasons in Jimma Zone, South West Ethiopia. J. Env. Earth Sci., vol. 7, 3. 2017.

49. Zamanian M, Aziz-Soleiman F. Honey and glycemic control: A systematic review. Pharmanutrition, vol. 11, 100180 . 2020. http://doi.org/10.1016/j.phanu.2020.100180.

50. Samhita S, Susruta SS, Adhyaya D, Varga M. 45/132-142, edited by VaidyaJadavajiTrikamjiAcharya, 7th edition, ChaukhambaOrientalia, Varanasi,;207-8. 2002.

51. DavisC. The Use of Australian Honey in Moist Wound Management . RIRDC Web Publication No W05/159. 2005.

52. Samarghandian S, Afshar JT, DavoodiS. Chrysin reduces proliferation and induces apoptosis in the human prostate cancer cell line pc-3. Clinics, vol. 66, 1073-1079. 2011.

53. Gannabathula S,. Skinner MA, Rosendale D, Greenwood JM, Mutukumira AN, Gregor S, Jonathan S, Krissansen GW, Schlothauer RC. Arabinogalactan protein contribute to the immune 
stimulatory properties of New Zealand honey. Immunopharmacol. and Immunotoxicology, 2011; 1-10. DOI: 10.3109/08923973.2011.641974. 2012.

54. Irish J, Blair SK, Carter DA. The antibacterial activities of Honey derived from Australian flora. PloS ONE, 6(3): e 18229. 2011. Doi :10.1371/journal.pone.0018229.

55. Yoshimasa ITO. Local honey production activities and their Significance for local people: a case of mountain forest area of southwestern Ethiopia. Afric. Study Monographs, Suppl., vol. 48: 7797. 2014.

56. Eimad dine Tariq Bouhlali, Mohamed Bammou, Khalid Sellam, Adil El Midaoui, Bouchra Bourkhis, Jamal Ennassir, ChakibAlem,YounesFilali-Zegzouti. Physicochemical properties of eleven monofloral honey samples produced in Morocco, Arab Journal of Basic and Applied Sciences, 26:1, 476-487. 2019. DOI: 10.1080/25765299.2019.1687119

57. Mekonnen N,Abebe E. Ethnobotanical knowledge and practices of traditional healers in Harar, Haramaya, Bati and Garamuleta, Eastern Ethiopia, Ethiopian Veterinary Journal, vol. 21, no. 2, pp. 40-61. 2017.

58. Borah MP, Prasad SB. Ethnozoological study of animals basedmedicine used by traditional healers and indigenous inhabitants in the adjoining areas of Gibbon Wildlife Sanctuary, Assam, India. J. Ethnobiol and Ethnomed., vol. 13:39. 2017. DOI 10.1186/s13002-017-0167-6.

59. Kindie FA, Mekuriaw SA, Dagnew MA. Ethnozoological study of traditional medicinal appreciation of animals and their products among the indigenous people of Metema Woreda, North-Western Ethiopia. J. Ethnobiol. Ethnomed.,vol.14:37. 2018.

60. Carnwath R, Graham EM, Reynolds K, Pollock PJ.The antimicrobial activity ofhoney against common equine wound bacterial isolates. Vet.J.,vol. 199, 110-114. 2014. Doi:10.1016/j.tvj1.2013.07.003. 
Figures

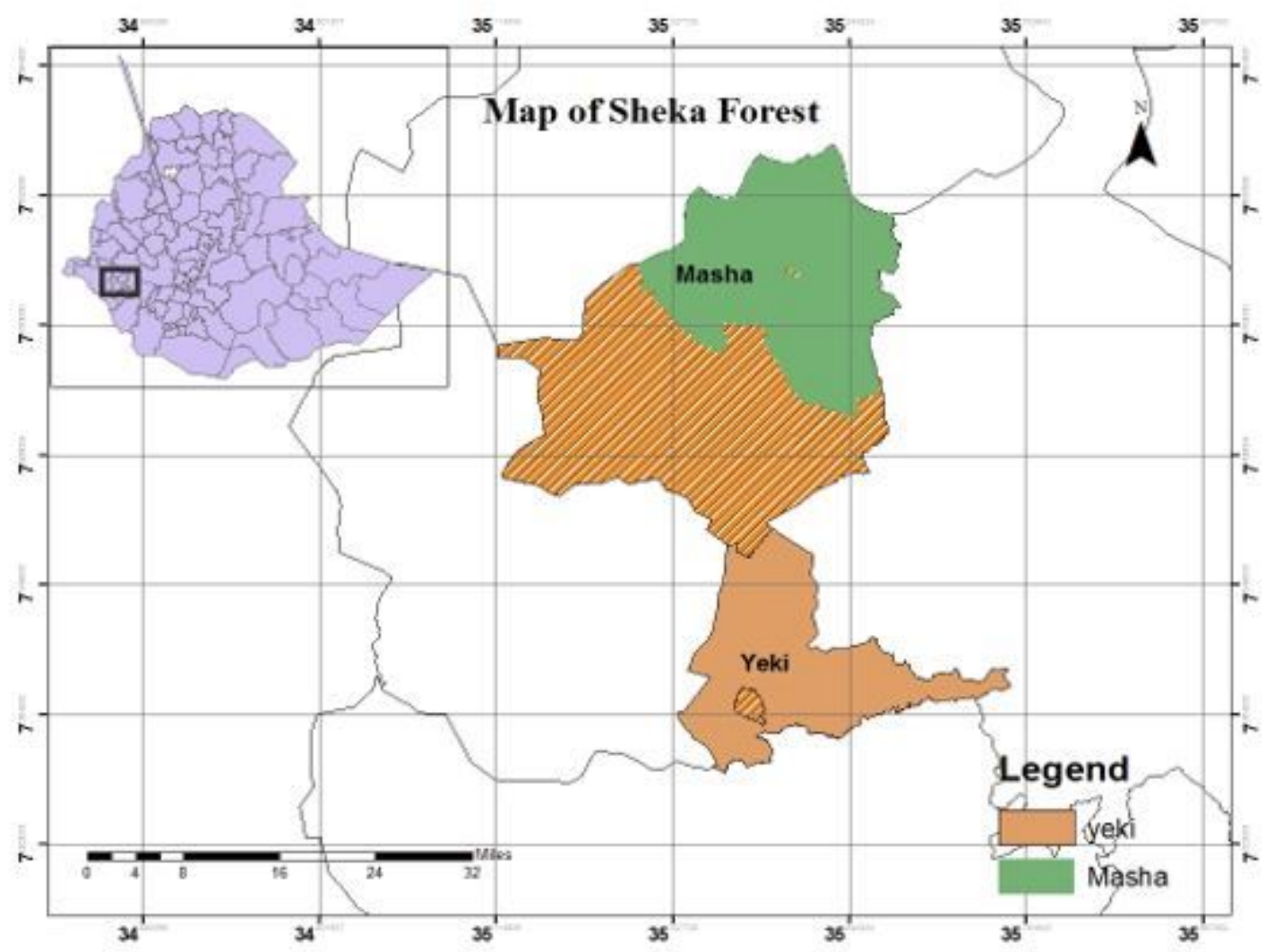

Figure 1

Map of the study area 